\title{
Governing Democracy Outside the Law: India's Election Commission and the Challenge of Accountability
}

\author{
M. Mohsin Alam Bhat \\ Professor, Jindal Global Law School; Executive-Director, Centre for Public Interest Law, at O.P. Jindal Global University, \\ Sonepat, India \\ Corresponding author. E-mail: mabhat@jgu.edu.in
}

(Received 16 September 2021; accepted 16 September 2021)

\begin{abstract}
Comparative law and politics literature widely recognizes the role of election management bodies (EMBs) in securing the well-being of constitutional democracies. Scholars have noted the political desirability of both independence and accountability of these institutions. But striking balance between these two values is easier said than done. This Article highlights the dilemma of accountability by focusing on India's Election Commission (ECI) as a paradigmatic version of a powerful EMB. Scholars of Indian politics have long noted the institution's widening powers - often beyond the original constitutional intent or parliamentary legislation - over the last few decades. This, they argue, has impaired its institutional accountability. This Article adopts a fresh perspective on the ECI's expansive functions, and the attendant concerns these raise. It argues that the ECI regulates the electoral process not through what we may ordinarily identify as the law. The most compelling and consequential of its functions are through extra-legal modalities of regulation. Drawing from recent scholarship on regulation, the Article argues that the ECI shapes the electoral environment and behaviour through non-legal modalities of architecture, nudge and notice-based regulations. Much like the other fields where they are deployed, these extra-legal modalities exhibit unique, and in many ways, inherent limitations with respect to transparency. It is thus this character of the ECI's functions - rather than only their widening breadth - that poses the most significant challenge for democratic accountability. Based on this assessment, the Article notes that for powerful EMBs like the ECI, accountability in the form of on-going operational accountability is inherently limited in compelling ways. This increases the stakes for accountability of these institutions through other means, particularly by securing their constitution, composition and tenure.
\end{abstract}

There has been increasing scholarly appreciation for the role of fourth branch institutions in securing the health, vibrancy and longevity of constitutional democracies. ${ }^{1}$ One of the most significant of these institutions, election management bodies (EMBs), are especially crucial for preserving the integrity of democratic processes. ${ }^{2}$ Political insulation allows EMBs to prevent capture and

\footnotetext{
${ }^{1}$ See Bruce Ackerman, 'The New Separation of Powers' (2000) 113 Harvard Law Review 633; Mark Tushnet, 'Institutions Protecting Constitutional Democracy: Some Conceptual and Methodological Preliminaries' (2020) 70(2) University of Toronto Law Journal 95; Mark Tushnet, 'Institutions Protecting Democracy: A Preliminary Inquiry' (2018) 12(2) Law \& Ethics of Human Rights 181.

${ }^{2}$ See eg, Helena Catt et al, 'Electoral Management Design: Revised Edition' (Stockholm, International IDEA 2014) <https:// www.idea.int/data-tools/data/electoral-management-design> accessed 30 June 2021; Mamoudou Gazibo, 'The Forging of Institutional Autonomy: a Comparative Study of Electoral Management Commissions in Africa' (2006) 39(3) Canadian Journal of Political Science 611; Jonathan Hartlyn, Jennifer McCoy \& Thomas M Mustillo, 'Electoral Governance Matters: Explaining the Quality of Elections in Contemporary Latin America' (2008) 41 Comparative Political Studies 73; Michael Pal, 'Electoral Management Bodies as a Fourth Branch of Government' (2016) 21(1) Review of Constitutional Studies 85.

(C) The Author(s), 2021. Published by Cambridge University Press on behalf of the National University of Singapore. This is an Open Access article, distributed under the terms of the Creative Commons Attribution licence (https://creativecommons.org/licenses/by/4.0/), which permits unrestricted re-use, distribution, and reproduction in any medium, provided the original work is properly cited.
} 
subversion of democracy. Scholars have, at the same time, noted the need for stronger accountability of EMBs. ${ }^{3}$ Institutional accountability maintains public trust, and impedes their capture by ruling majorities. Yet striking a balance between independence and accountability is easier said than done. ${ }^{4}$ Powerful EMBs in particular exercise wide-ranging, and often complex and granular functions, which other institutions may not always be in a position to assess. This Article directly addresses this issue. It seeks to show how and why the functioning of powerful EMBs pose a special problem for accountability, and draws lessons to overcome this difficulty.

This Article focuses on the Election Commission of India (ECI) to explore the tensions between independence and accountability. The ECI is in many ways a paradigmatic version of a powerful EMB. ${ }^{5}$ It is a permanent institution set up under Article 324 of the Indian Constitution. The Constitution provides for the appointment of the ECI's members, and secures the tenure and conditions of service of its chief election commissioner (CEC). ${ }^{6}$ It gives the Commission the power to supervise, direct and control the conduct of elections, ${ }^{7}$ which includes the crucial task of preparing electoral rolls for all national and local elections. Parliament and state legislatures have the power to legislate on electoral matters. ${ }^{8}$ Indeed, Parliament exercised this authority in 1950 and 1951, when it enacted the principal election legislation in the form of the Peoples Representation Acts (RPAs). But since its inception, and particularly since the 1990s, the ECI has gone beyond the strict confines of these framework laws. It has laid down new rules, processes and mechanisms, most notably in relation to the registration of political parties, disclosure requirements for candidates, and enforcing election campaign standards. Scholars of India's democratic process have highlighted, with varying degrees of concern, the institution's growing breadth of powers. They have noted that the ECI's expansion of its own functions - without legislative sanction or public deliberation - presents a problem of accountability. ${ }^{9}$

\footnotetext{
${ }^{3}$ There has been a tremendous increase in policy and scholarly literature advocating the need for transparency and accountability of EMBs recently. For some of the relevant literature, see Helena Catt et al (n 2) 223; Pippa Norris \& Alessandro Nai (eds), Election Watchdogs: Transparency, Accountability and Integrity (Oxford University Press 2017); Alexander B Makulilo \& Eugene Ntaganda, Election Management Bodies in East Africa (African Minds 2016).

${ }^{4}$ For some literature referring to this dilemma, see Shaheen Mozaffar \& Andreas Schedler, 'The Comparative Study of Electoral Governance - Introduction' (2002) 23 International Political Science Review 5, 10; Pippa Norris, 'Transparency in Electoral Governance', in Pippa Norris \& Alessandro Nai (eds), Election Watchdogs: Transparency, Accountability and Integrity (Oxford University Press 2017) 3, 10; Pierre de Vos, 'Balancing Independence and Accountability: The Role of Chapter 9 Institutions in South Africa's Constitutional Democracy', in Danwood Chirwa \& Lia Nijzink (eds), Accountable Government in Africa: Perspectives from Public Law and Political Studies (UCT Press 2012) 160.

${ }^{5}$ For the classification of EMBs, see Michael Pal, 'Partisan Manipulation of the Democratic Process and the Comparative Law of Democracy' (SJD Thesis, University of Toronto 2014) 79-84, and the references cited therein. The ECI has historically enjoyed a high degree of public trust. See Ujjwal Kumar Singh \& Anupama Roy, Election Commission of India (Oxford University Press 2019) 37-38.

${ }^{6}$ Constitution of India, art 324(5). For a general overview of the ECI under the constitution, see Arun K Thiruvengadam, The Constitution of India: A Contextual Analysis (Hart Publishing 2017) 148-156; ibid 29-34.

${ }^{7}$ Constitution of India, art 324(1).

${ }^{8}$ Constitution of India, Seventh Schedule (list I, entry 72; list II, entry 37).

${ }^{9}$ See eg Alistair McMillan, 'The Election Commission of India and the Regulation and Administration of Electoral Politics' (2012) 11(2) Election Law Journal: Rules, Politics, and Policy 187; Ujjwal Kumar Singh, 'Between Moral Force and Supplementary Legality: A Model Code of Conduct and the Election Commission of India' (2012) 11(2) Election Law Journal: Rules, Politics, and Policy 149, 166 (quoting Partha Chatterjee's critique of the ECI); Manjari Katju, 'Election Commission and Functioning of Democracy' (2006) 41(17) Economic and Political Weekly 1635; Singh \& Roy (n 5) 39, 331-332. For the rise in the political significance of the ECI more generally, see Susanne Hoeber Rudolph \& Lloyd I Rudolph, 'South Asia Faces the Future: New Dimensions of Indian Democracy' (2002) 13 Journal of Democracy 52; Eswaran Sridharan \& Milan Vaishnav, 'Election Commission of India', in Devesh Kapur, Pratap Bhanu Mehta \& Milan Vaishnav (eds), Rethinking Public Institutions in India (Oxford University Press 2018) 417, 425, (noting the ECI's "regulatory expansionism" and "regulatory activism"); Amit Ahuja \& Susan L Ostermann, "From Quiescent Bureaucracy to "Undocumented Wonder”: Explaining the Indian Election Commission's Expanding Mandate' (2018) 31(4) Governance 759.
} 
This Article adopts a fresh perspective on the functioning of the ECI to illuminate the specific challenges of institutional accountability. I argue that it is not so much the extent of the ECI's functions, but their character that poses a special problem for accountability. The Article shows that the ECI primarily regulates the electoral process not through what we may ordinarily consider as the law, in the form of rules for guiding behaviour and prohibitions backed by sanction. Rather, the ECI regulates by structuring, steering and framing the electoral process. These forms of electoral governance fit with what regulation scholars have recently started identifying as extra-legal modalities of regulation in a range of fields. ${ }^{10}$ These scholars have noted that legal regulation is just one of the many diverse ways in which regulators shape behaviour. Regulators may adopt architectural regulation that alter the physical or digital environment that makes undesirable activity impossible. They may nudge towards desirable behaviour by altering the way in which people access goods or services. They may also mandate disclosure of information, in the form of notice requirements, which will impact the electoral choices people make. These modalities are not legal - in the sense of being guidance backed by penalties - and yet significantly determine how people choose or behave. I show in Parts I-IV that the most visible and pioneering regulations in the ECI's repertoire use these modalities of architecture, nudge and notice - or ANN regulations in short - to regulate India's democratic process.

This account reveals what it is that makes the ECI so powerful and consequential for the Indian democratic process. The ECI is not merely a vehicle of narrowly-conceived election management. ${ }^{11}$ Its functions, which are regulative in nature, constitute electoral strategy and choice. This regulative character of its functions grants immense power to the ECI. As I also argue, however, there has not been a full appreciation of this dynamic. Much of the regulatory expansion of the ECI has occurred with the endorsement of courts. While courts have gestured towards the peculiarity of the ECI's widening functions, the jurisprudence has yet to evolve a precise vocabulary for these functions or fully reckon with their consequences.

This interpretive account of the ECI's functions has important implications for our assessment of its accountability. ${ }^{12}$ I argue in Part IV that ANN regulations have the potential of being pervasive and insidious. While they can have the same or sometimes more impact on behaviour compared to ordinary legal rules, they may escape public scrutiny. ANN regulations consequently raise concerns of accountability, specifically for on-going oversight in the form of operational accountability. The ECI's functions by extension pose the same inherent - and in many ways intractable - challenges. This approach to accountability - mindful of the regulatory character of the ECI's functioning throws new light on the global conversation on EMBs. Scholars have usually interpreted the challenge of accountability as resulting from the wide administrative discretion of EMBs, which in turn require stronger strategies of oversight and consultation. ${ }^{13}$ My account shows that at least in the case

\footnotetext{
${ }^{10}$ See eg, Bronwen Morgan \& Karen Yeung, An Introduction to Law and Regulation: Text and Materials (Cambridge University Press 2007) 80-102 (noting that regulatory instruments may be of various types like command, competition, consensus, communication and code); Lawrence Lessig, Code Version 2.0 (Basic Books 2006) (arguing that apart from the law, social norms, market, and architecture or "code" are also modalities of regulation); Ryan Calo, "Code, Nudge, or Notice' (2013) 99 Iowa Law Review 773 (identifying the synergies among non-legal regulations through architecture, nudge and notice, and suggesting safeguards in these context.).

${ }^{11}$ Election management or administration ordinarily refers to a variety of activities like voter registration, staff training, conducting and observing elections, and vote count and audit. See Thad E Hall, 'Election Administration', in Erik S Herron, Robert J Pekkanen \& Matthew S Shugart (eds), The Oxford Handbook of Electoral Systems (Oxford University Press 2018) 475.

${ }^{12}$ In this Article, I shall exclusively focus on what Pippa Norris calls "horizontal accountability", referring to accountability of EMBs by other state institutions like legislatures and courts. This is because in India, state institutions - not the international community or civil society - historically and institutionally play a significant role of the institution's accountability. See Norris (n 4) 3, 12.

${ }^{13}$ See eg Shaheen Mozaffar \& Andreas Schedler, 'The Comparative Study of Electoral Governance - Introduction' (2002) 1 International Political Science Review 5, 10 (arguing that since the "ambiguity and indeterminacy" of electoral rules require
} 
of powerful EMBs like the ECI, the regulatory powers are not always meaningfully amenable to ordinary mechanisms of operational accountability. The best route to the ECI's accountability, I conclude, is to invest more political energy in structural accountability by securing its independence, competence and neutrality. Still, structural accountability has hitherto been precarious at best. In Part V, I highlight some of the key deficits in this regard, and critique the Indian Supreme Court's position on the subject.

The appreciation of the character of the ECI's functions and the inherent challenges of operational accountability, I advocate, behooves India's political and judicial institutions to re-evaluate and strengthen the conditions of its independence and competence. It also invites scholars to pay attention to the regulative - not only managerial - working of EMBs, which structure and constitute democratic processes in profound ways.

\section{Regulating electoral architecture}

Under India's election legislative framework, the ECI prepares voter rolls, registers candidates, organizes voting and counting, and verifies and announces results. ${ }^{14}$ It also exercises significant functions, outside this legislative framework and with a profoundly wide discretion, which constitute the terms of access and participation of candidates and voters. The ECI has complete discretion to decide the number and location of polling stations and booths. ${ }^{15}$ It has power to schedule, re-schedule and adjourn elections. ${ }^{16}$ The Commission also provides procedures for the recognition and registration of political parties. ${ }^{17}$ These functions structure the electoral environment by providing the gateways, paths and boundaries for electoral behaviour. Such regulations fit with what regulation scholars have called architectural regulation.

\section{Contours of architectural regulation}

Architectural regulations are different from legal regulations in at least three important respects: focus, modus operandi and efficacy. First, unlike legal regulations that rely on communication to guide subjects of regulation, architectural regulations focus on shaping, in David Garland's words, "the social processes and arrangements that they inhabit." ${ }^{18}$ Legal regulation that seeks to alter the behaviour of the subject regulates them directly, through legal guidance. Architectural regulation seeks to guide the behaviour indirectly, by altering the subject's context. According to Garland, such regulation,

aims to embed controls in the fabric of normal interaction.... Rather than rely upon the uncertain threat of deterrent sentences, or the dubious ability of the police to catch villains, it sets in place a more mundane set of reforms, designed not to change people but to redesign things and reshape situations. A thousand small adjustments are required. Replace cash with credit cards. Build locks into the steering columns of automobiles. Employ attendants in parking lots and use close circuit TV cameras to monitor city centre streets. Co-ordinate the closing times of rival clubs and discos. Lay on late night buses and special routes to and from football

\footnotetext{
EMBs to exercise "some measure of administrative discretion", there may be a need for oversight, monitoring, transparency, and broad-based consultation to ensure public accountability.).

${ }^{14}$ See generally The Representation of the People Act 1951.

${ }^{15}$ The Representation of the People Act 1951, s 25.

${ }^{16}$ See generally VS Rama Devi and SK Mendiratta, How India Votes: Election Laws, Practice and Procedure (4th ed, LexisNexis 2017) 493-518.

${ }^{17}$ ibid 583-656.

${ }^{18}$ David Garland, The Culture of Control: Crime and Social Order in Contemporary Society (University of Chicago Press 2012) 183.
} 
games. Advise retailers about security. Encourage local authorities to co-ordinate the various agencies that deal with crime. Remind citizens of the need to safeguard their property and supervise their neighbourhoods. ${ }^{19}$

Thus, as Roger Brownsword evocatively puts it, this regulation "by-passes practical reason altogether." ${ }^{20}$ A familiar example is the speed bump, which regulators may use over and above legally enforcing speed limits to reach the same effect. Crime prevention may also adopt such physical architecture-based regulation. ${ }^{21}$ Neal Katyal for instance advocates designing physical spaces to control crime. ${ }^{22}$ Designers can build more visible spaces to increase public surveillance, and indirectly reduce crime. ${ }^{23}$ They may also create design features that enhance a sense of ownership among the residents, like real or symbolic barriers. ${ }^{24}$ Street design can incorporate signs, street limits and other mechanisms of slowing traffic to reduce the violations of law. ${ }^{25}$

Second, in focusing on design, this modality regulates the terms of participation for subjects. As Lawrence Lessig famously noted, architecture - or what he calls "Code" - is often the most important modality through which the Internet is regulated. The Code is the "built environment" of cyberspace." ${ }^{26}$ It is, according to Lessig, "experienced as conditions on your access to cyberspace."

Third, unlike legal regulation, architectural regulation does not need to depend on ordinary legal enforcement for its effectiveness. Rather than prosecution, it relies on making certain behaviour impossible. ${ }^{28}$ It regulates in order to "minimize the opportunities for disruption and deviance." 29 As regulation scholars Morgan and Yeung note, architecture-based regulation seeks to "eliminate undesirable behaviour by designing out the possibility for its occurrence." ${ }^{30}$ The core feature of such regulation is that it determines the terms of participation, activity and behaviour to such an extent that the subjects of regulation, as Brownsword puts it, have "no choice at all but to act in accordance with the desired regulatory pattern." ${ }^{31}$ While architectural regulation is often obscure because the actors may not perceive it as regulating their behaviour, it matters as a modality of regulation because it is efficacious.

\footnotetext{
${ }^{19}$ ibid 129 (emphasis added).

${ }^{20}$ Roger Brownsword, 'Code, Control, and Choice: Why East is East and West is West' (2005) 25 Legal Studies 1.

${ }^{21}$ See eg Ronald V Clarke, 'Situational Crime Prevention' (1995) 19 Crime and Justice 91, 94; Paul Ekblom, 'Less Crime, by Design' (1995) 539 The Annals of the American Academy of Political and Social Science 114, 115; Ronald V Clarke, 'Situational Crime Prevention: Its Theoretical Basis and Practical Scope' (1983) 4 Crime and Justice 225, 233-241; Neal Kumar Katyal, 'Architecture as Crime Control' (2002) 111 The Yale Law Journal 1039, 1042.

${ }^{22}$ Katyal (n 21).

${ }^{23}$ ibid $1050-1058$

${ }^{24}$ ibid 1060 .

${ }^{25}$ ibid.

${ }^{26}$ Lessig (n 10) 124 .

${ }^{27}$ ibid.

${ }^{28}$ According to Lessig, the Code "embeds certain values or makes certain values impossible." As he illustrates in the context of the Internet, "[i]n some places...you must enter a password before you gain access; in other places you can enter whether identified or not. In some places the transactions you engage in produce traces that link the transactions (the "mouse droppings") back to you; in other places this link is achieved only if you want it to be... The code or software or architecture or protocols set these features, which are selected by code writers. They constrain some behaviour by making other behaviour possible or impossible." Lessig (n 10) 124-125.

${ }^{29}$ Brownsword (n 20) 12.

${ }^{30}$ Morgan \& Yeung (n 10) 102.

${ }^{31}$ See Edward K Cheng, 'Structural Laws and the Puzzle of Regulating Behavior' (2006) 100(2) Northwestern University Law Review 655 (noting that architectural regulation's "philosophy is more preventive, rather than reactive."); Calo (n 10) 775; Giovanni Sartor, 'Human Rights and Information Technologies' in Roger Brownsword, Eloise Scotford \& Karen Yeung (eds), The Oxford Handbook of Law, Regulation and Technology (Oxford University Press 2017) 424, 432 (“...prohibitions can transform into inabilities, as unwanted actions become impossible (or more difficult or costly) within such technological environments, and obligations can transform into necessities, that is, actions that have to be performed if one wants to use the infrastructure.").
} 


\section{The ECl's architectural regulation}

An accessible example of the ECI's architectural regulation is its exclusive control over physical infrastructure like polling stations and booths. The locations of polling station determine the costs of participation for voters, ${ }^{32}$ and thus electoral outcomes. This function is an exercise of architectural regulation, because while it does not directly involve laying down rules of conduct, it indirectly incentivizes or disincentivizes through design. The ECI's most significant architectural regulation, though, is how it regulates non-physical aspects of the electoral environment. I will focus here on two examples: the registration of political parties, and determination of election schedules. In both these instances, the ECI has focused regulation on the design of electoral activity, or in other words, the electoral architecture. This regulation matters because it constitutes the behaviour of political actors. I will also show how the ECI's architectural regulation has expanded with judicial endorsement. The courts though have only partially appreciated the character and implications of this expansion.

Let us start with the regulation of political parties. The Indian Constitution (1950) and the legislative framework (RPAs 1950 and 1951) did not initially regulate political parties. This was despite the fact that the post-independence democratic system, borrowing from the Westminster model, was party-political in practice. It was much later in the 1980s that a series of legal measures brought political parties under the cover of the law. A constitutional amendment in 1985 provided for the disqualification of members of parliament who defected from their parties. ${ }^{33}$ Election legislation incorporated provisions for party registration in $1989 .{ }^{34}$ These measures sought, and perhaps succeeded to formalize the party-political nature of India's electoral system. They secured the integrity and stability of parties, by centralizing party structures, and arguably enhancing the control of party leadership over politicians. ${ }^{35}$ These measures thus transformed the Indian democratic system from candidate- to party-centred.

The ECI's regulations on political parties were a precursor to these legal developments. The route was indirect, through the allocation of party symbols. In the first general election in 1952, the ECI allocated pictorial symbols to candidates and parties to facilitate the democratic choice of a vast majority of unlettered voters. ${ }^{36}$ The Executive laid down rules in 1961, under its legislatively specified powers, that allowed the ECI to allocate symbols to candidates. ${ }^{37}$ In 1968, the ECI formalized the system by issuing the Election Symbols (Reservation and Allotment) Order (the Order). The Order, though, exceeded the boundaries of the legislative framework. Rather than treating candidates as the unit of regulation, it was primarily party-centric. The ECI was well-aware of this. It invoked both the government rules and Article 324 of the Constitution directly as the bases of

\footnotetext{
${ }^{32}$ While research on this appears to be non-existent in the case of India, a large body of work deals with this question outside, particularly in the United States. See eg, Moshe Haspel \& H Gibbs Knotts, 'Location, Location, Location: Precinct Placement and the Costs of Voting' (2005) 67(2) The Journal of Politics 560 (arguing that "changes in the location of a polling place or small differences in the distance one must travel in order to vote can both have significant impacts on a citizen's likelihood of voting.”); Abraham M Rutchick, 'Deus Ex Machina: The Influence of Polling Place on Voting Behavior' (2010) 31(2) Political Psychology 209 (arguing that "the places in which people vote can serve as primes that influence their attitudes and behavior."); Henry E Brady \& John E McNulty, 'Turning Out to Vote: The Costs of Finding and Getting to the Polling Place' (2011) 105 The American Political Science Review 115.

${ }^{33}$ Constitution of India, Tenth Schedule. See Csaba Nikolenyi \& Shaul R Shenhav, 'The Constitutionalisation of Party Unity: The Origins of Anti-defection Laws in India and Israel' (2015) 21(3) The Journal of Legislative Studies, 390.

${ }^{34}$ The Representation of People Act 1951, ss 29A-29C.

${ }^{35}$ See Aradhya Sethia, 'Where's the Party?: Towards a Constitutional Biography of Political Parties' (2019) 3 Indian Law Review 1.

${ }^{36}$ Ramachandra Guha, 'Democracy's Biggest Gamble: India’s First Free Elections in 1952' (2002) 19(1) World Policy Journal 95, 96. Also see generally Ornit Shani, How India Became Democratic: Citizenship and the Making of the Universal Franchise (Cambridge University Press 2017).

${ }^{37}$ The Conduct of Elections Rules 1961, r 5 (the provision states that the ECI would "specify the symbols that may be chosen by candidates at elections in parliamentary or assembly constituencies and the restrictions to which their choice shall be subject.").
} 
its power in the text of the Order. ${ }^{38}$ The Order provided detailed procedures and parameters of party recognition and classification. It divided parties into categories of recognized and unrecognized, and national and state. ${ }^{39}$ Associations seeking to be registered as political parties were expected not only to have a clear party structure and hierarchy, but also share with the ECI their aims, policies and principles. ${ }^{40}$ Under the Order, the ECI gave itself complete discretion regarding the registration and classification of a political party. ${ }^{41}$ It also gave itself the power to adjudicate on the use of symbols in cases of disputes or party splits. ${ }^{42}$ Parliament eventually incorporated these regulations into legislation in $1989 .{ }^{43}$

By offering uniform symbols across constituencies that would be better recognized by the voters, the Order indirectly shaped political parties, including their internal structure and common purpose. To what extent it actually expanded and entrenched political parties is an empirical question, and thus outside the scope of this Article. But irrespective of this empirical assessment, the character of the Order as regulation should be clear. It constituted electoral architecture as primarily party-centric. The ECI conducted a gatekeeping function and determined the terms of electoral participation. In doing so, importantly, it also placed itself as the central arbiter and regulator of political parties.

The constitutional stakes of the ECI's architectural regulation were first explicit in the 1985 case of Kanhaiyalal Omar. ${ }^{44}$ The petitioner who filed the public interest litigation in the Supreme Court claimed that the ECI had formalized party politics beyond what the existing legal framework provided. The Order was, in the petitioner's view, "legislative in character" ${ }^{45}$ and thus outside the competence of the ECI. The Court acknowledged and endorsed the Order's constitutive impact on the electoral landscape. The "use of a symbol", the Court noted, had a "unifying effect amongst the people with a common political and economic programme." ${ }^{\text {"T }}$ The symbols would help in "the establishment of a Westminster type of democracy" 47 that India had adopted, and in which political parties were implicit. The Court also accepted that the Order was outside the legislative framework. But it rejected the argument that the ECI did not have the power to enact it. It held that it was competent to enact the Order under Article 324, which was "plenary in character" 48 and "operate[d] in areas left unoccupied by legislation". ${ }^{49}$ These powers, the Court held, "should be construed liberally so that the object for which the power is granted is effectively achieved." ${ }^{50}$ About the character of the ECI's powers to enact the Order, the Court noted that,

\footnotetext{
${ }^{38}$ The Election Symbols (Reservation and Allotment) Order 1968, preamble.

${ }^{39}$ The Election Symbols (Reservation and Allotment) Order 1968, para 6.

${ }^{40}$ The Election Symbols (Reservation and Allotment) Order 1968, para 3. This paragraph was repealed in 1992, presumably because Parliament introduced mechanisms for party registration, by amending the RPA 1951 and including ss $29 \mathrm{~A}-$ 29C in 1989.

${ }^{41}$ This was reflected in the initial version of the Order. See The Election Symbols (Reservation and Allotment) Order, 1968, para 3. The current position is reflected under the RPA 1951. See The Representation of People Act 1951, s 29A(8).

${ }^{42}$ The Election Symbols (Reservation and Allotment) Order 1968, paras 15-16.

${ }^{43}$ See The Representation of People Act, 1951, s 29A.

${ }^{44}$ Kanhiyalal Omar v RK Trivedi [1985] 4 SCC 628 (hereinafter "Kanhaiyalal Omar"). The early cases in the Supreme Court dealt with disputes over splinter political parties and the ECI's adjudicatory powers under the Order. In these cases, the Court, following the parties in dispute, assumed the jurisdiction of the ECI to regulate political parties in the context of symbols. See Sadiq Ali v Election Commission of India [1972] 4 SCC 664; All Party Hill Leaders' Conference, Shillong $v$ MA Sangma [1978] 1 SCR 393; Roop Lal Sathi v Nachhattar Singh [1982] 3 SCC 487.

${ }^{45}$ Kanhaiyalal Omar (n 44) para 1.

${ }^{46}$ ibid para 10.

${ }^{47}$ ibid para 10 .

${ }^{48}$ ibid para 16.

${ }^{49}$ ibid para 16.

${ }^{50}$ ibid para 17.
} 
[while] construing the expression 'superintendence', 'direction and control' in Article 324(1), one has to remember that every norm which lays down a rule of conduct cannot possibly be elevated to the position of legislation or delegated legislation. There are some authorities or persons in certain grey areas who may be sources of rules of conduct and who at the same time cannot be equated to authorities or persons who can make law, in the strict sense in which it is understood in jurisprudence... [T] he source of power in this case is the Constitution... ${ }^{51}$

Here was an appreciation by the Court that the ECI's power to regulate electoral architecture was at the boundaries of ordinarily-understood legal authority, and yet constitutionally permitted.

The ECI's most ambitious attempt at regulating political parties has been its demand to be formally given the power to de-register. ${ }^{52}$ But at present, because of a Supreme Court decision, ${ }^{53}$ the ECI does not have the power to de-register political parties apart from narrow set of technical grounds. Despite this, the ECI has used the Order as an avenue to regulate parties and enforce electoral standards on an on-going basis. It amended the Order in 1994 to add a provision permitting it to withdraw symbols from parties that did not comply with the ethical norms of "free, fair and peaceful elections" or "the interests of the general public and the electorate." 54 The ECI has threatened to de-recognize political parties that violate these terms, including not conducting their internal affairs in consonance with party constitutions. This, in some ways, has at least theoretically opened the space for the ECI to enforce internal democracy and process in political parties. ${ }^{55}$

Apart from a broad interpretation of the ECI's "plenary power", two more aspects of the jurisprudence are worth noting. First, courts have consistently adopted a highly deferential approach to the breadth of the ECI's powers. ${ }^{56}$ For instance in a case dealing with the ECI's authority to adjudicate allocation of symbols in cases of party splits, the Court ruled that courts should be deferential to the ECI's procedures and criteria to adjudicate such matters. "The fact that the power...has been vested in such a high authority", Khanna J noted, "raise[d] a presumption, though rebuttable, and provide a guarantee, though not absolute but to a considerable extent, that the power would not be misused but would be exercised in a fair and reasonable manner." 57

\footnotetext{
${ }^{51}$ ibid para 17 (emphasis added).

${ }^{52}$ Numerous government committee report, including recommendations by the ECI, have suggested incorporating the power to de-register political parties. See Election Commission of India, 'Proposed Electoral Reforms' (December 2016) 34-37 <https://eci.gov.in/files/file/9236-proposed-election-reforms> accessed 1 January 2021.

${ }^{53}$ See Indian National Congress (I) v Institute of Social Welfare [2002] 5 SCC 685. The Court ruled at para 40 that since the legislative framework does not provide this power explicitly, the ECI cannot de-register political parties. Such powers, the Court held, would invite the ECI "in matters of a political nature", since it would mandate the institution to monitor "the political activities, programmes and ideologies of political parties." Nevertheless, the Court ruled that the ECI could de-register political parties if they had attained registration through fraud, changed their internal rules to indicate that it had "ceased to have faith and allegiance to the Constitution of India or to the principles of socialism, secularism and democracy or it would not uphold the sovereignty, unity and integrity of India" as required under section 29A, or in any case where the ECI would not need to conduct an inquiry like the declaration of a political party as a terrorist organization under existing criminal law (see para 35).

${ }^{54}$ The Election Symbols (Reservation and Allotment) Order 1968, para 16A.

${ }^{55}$ There has been some serious policy attention on holding political parties accountable to internal democracy and accountability. Most recently, India's Law Commission suggested a series of reforms in this context. Despite this, there exists no institutionalized process for this under Indian election law. For the Law Commission's recommendation on the issue, see Law Commission of India, 'Report No. 255: Electoral Reforms' (March 2015) 69-79 <https:/lawcommissionofindia.nic.in/ reports/report255.pdf> accessed 30 May 2021. For a succinct review on these policy developments, see Ruchika Singh, 'Is There Intra-party Democracy in Indian Political Parties?' (The Hindu Centre for Politics and Public Policy, 12 April 2014) $<$ https://www.thehinducentre.com/verdict/get-the-fact/article5896168.ece> accessed 30 May 2021.

${ }^{56}$ For a discussion of judicial deference to the ECI, see M Mohsin Alam Bhat, 'Between Trust and Democracy: The Election Commission of India and the Question of Constitutional Accountability', in Swati Jhaveri, Tarunabh Khaitan \& Dinesha Samararatne (eds), Constitutional Resilience Beyond Courts: Views from South Asia (Bloomsbury Publishing 2022) (forthcoming).

${ }^{57}$ Sadiq Ali (n 44) para 40 (emphasis added).
} 
Second, courts in some instances have also held that the ECI's architectural regulation could trump parliamentary law. The ECI has thus been interpreted to be a co-equal - and sometimes overriding - authority in laying down electoral architecture. This is most visible in the case of the ECI's discretion in scheduling elections. ${ }^{58}$ In the 2002 case of Gujarat Assembly Election Matter, ${ }^{59}$ the Supreme Court dealt with the power of the ECI to determine election schedules. Narendra Modi of the Bhartiya Janata Party (BJP), who was then a chief minister, dissolved the legislative assembly of the state of Gujarat - after it had witnessed gruesome anti-minority violence - nine months before the end of its five-year term. Critics worried that he wanted to take advantage of the polarization to win the election. The ECI, led by James Lyngdoh who had garnered a reputation of being an assertive CEC, ruled out early elections in the state. The Court held that there were no binding timelines explicitly provided in the Constitution. ${ }^{60}$ Moreover, parliamentary legislation provided that the ECI would recommend the election schedule to be notified by the Executive. Thus the Court concluded that the ECI had the authority to fix dates for elections. But the Court went further. It held that election schedules were part of the "plenary powers" of the ECI and within its "exclusive domain". ${ }^{61}$ This power was "not subject to any law framed by the Parliament." ${ }^{62}$ In fact, the Court held, if "Parliament makes any such law, it would repugnant to Article 324." $" 63$

The ECI, therefore, has over time come to exercise wide and significant regulative powers aimed at India's electoral architecture. These regulations are significant because they determine how various political actors - whether candidates or electors - access the electoral process. They distribute physical and non-physical infrastructure, place temporal limits on elections, and entrench a political party-centric polity. In important instances, the ECI's authority runs parallel to the ordinary legal framework, and sometimes even trumps parliamentary legislation. These features give enormous discretion to the ECI, transforming it from a managerial agency to a regulative institution that shapes the structure of Indian democracy.

\section{Nudging political actors}

In addition to the regulation of electoral architecture, the ECI also manages the Indian democratic process through what scholars of regulation have identified as nudges. The most prominent advocates of nudge, Richard Thaler and Cass Sunstein, define nudge as regulation that "steers people's choices, but it does not make their decisions for them." ${ }^{64}$ A nudge is the part of choice architecture that "alters people's behaviour in a predictable way without forbidding any options or significantly changing their economic incentives." ${ }^{\prime 65}$ A speedbump amounts to architectural regulation. But regulators may also guide behaviour by placing a visual sign - say, children crossing the road, or signs mentioning messages like 'Better late than Never' - to discourage driver from speeding. ${ }^{66}$ These kinds of regulations are nudges. They do not institute penalties for action or inaction, yet direct the subjects of regulation in directions that the regulators consider desirable.

\footnotetext{
${ }^{58}$ For scholarship on the significance of election schedules for determining voter behaviour, see Jason Roy \& Christopher Alcantara, 'The Election Timing Advantage: Empirical Fact or Fiction?' (2012) 31(4) Electoral Studies 774; C Rallings, M Thrasher \& G Borisyuk, 'Seasonal Factors, Voter Fatigue and the Costs of Voting' (2003) 22(1) Electoral Studies 65.

${ }^{59}$ In the Matter of Special Reference No. 1 of 2002 (Gujarat Assembly Election Matter) [2002] 8 SCC 237.

${ }^{60}$ ibid para 76.

${ }^{61}$ ibid para 76 .

${ }^{62}$ ibid para 80.

${ }^{63}$ ibid para 80 (emphasis added).

${ }^{64}$ Richard H Thaler \& Cass R Sunstein, Nudge: Improving Decisions about Health, Wealth, and Happiness (Yale University Press 2008) 244.

${ }^{65}$ Quoted in Anne van Aaken, 'Judge the Nudge: In Search of the Legal Limits of Paternalistic Nudging in the EU', in Alberto Alemanno \& Anne-Lise Sibony (eds), Nudge and the Law: A European Perspective (Hart Publishing 2015$) 83$.

${ }^{66}$ Calo (n 10) 776.
} 
The most profound example of the ECI regulating through nudging is its enforcement of the Model Code of Conduct (Code). ${ }^{67}$ The Code is a non-legislative document that enumerates 39 electoral ethics. Some of these codify legislative mandates. For instance, the Code incorporates the category of "corrupt practices" under the RPA, which includes bribery, appealing to elector's caste or religious identities, or incurring unauthorized expenditures. ${ }^{68}$ But the Code goes beyond the legislative mandate in two important ways. Substantively, it incorporates non-legislative grounds, like using official state machinery for electoral purposes and more recently, guidelines on party manifestos. Procedurally, the Code gives considerably wider range of options to the ECI to enforce electoral ethics. The legislative grounds under RPA can only be invoked at the end of an election, through normal legal routes, to challenge the election outcome. On the other hand, the ECI triggers the Code and implements it throughout the period of campaigning and elections. ${ }^{69}$ It imposes penalties on the candidates during the election process itself, often by prohibiting them from campaigning for a specified period of time.

There has been some debate about the character of the Code among the scholars of Indian democracy. The Code was born out of an inter-party consensus in 1960 during a state election. It was thus based on a political agreement over electoral morality, and may have been viewed as the most suitable mechanism of minimizing state capture by ruling parties. The ECI, as the only electoral regulator, started implementing this agreement by persuading political parties to endorse and follow the Code. The success of the Code eventually convinced major political parties to adopt it at the national level. It has since become the most well recognised and visible mode of electoral regulation. Since its inception, the Code's substantive expansion has been accompanied by an augmented and visible role of the ECI in enforcing it. ${ }^{70}$ These developments have led many commentators to advocate the legalization of the Code. But the dominant view within the ECI appears to be in favour of maintaining the non-legislative nature of the Code. A non-legal code is preferable because it permits the ECI to use it as an expeditious and flexible tool for electoral governance. ${ }^{71}$

Unsurprisingly, the non-legal nature of the Code has led some scholars to interpret it as reflecting the growing power of the ECI beyond what may have been originally intended. ${ }^{72}$ Singh and Roy for instance have described it as a form of "legal exceptionalism."73 Gilmartin and Moorg have described it as one of "the most distinctive features of Indian electoral oversight." ${ }^{74}$ Owing to the power the ECI exercises while implementing the Code, Gilmartin has called the institution "the law, if not above it." ${ }^{75}$ But the analysis of data on the Code's implementation during the latest 2019 national election cycle reveals something else. ${ }^{76}$ It shows that the Code is not so much an extraordinary mode of regulation. Rather, it resembles nudges that regulators in other fields have employed in ordinary course. We found that during the 2019 national elections cycle, a total of 433 complaints were filed against candidates or their agents. The ECI filed a sizable proportion, approximately 54 percent, of these complaints. The interesting finding was that the ECI did not

\footnotetext{
${ }^{67}$ Election Commission of India, 'Model Code of Conduct for the Guidance of Political Parties and Candidates' <https:// eci.gov.in/mcc> accessed 30 June 2021.

${ }^{68}$ See The Representation of People Act 1951, s 123.

${ }^{69}$ Devi \& Mendiratta (n 16) 681.

${ }^{70}$ See chapter "'Election Time' and the Model Code of Conduct” in Singh \& Roy (n 5).

${ }^{71}$ See chapter 9 of Shahabuddin Y Quraishi, An Undocumented Wonder: The Great Indian Election (Rupa Publications 2014).

${ }^{72}$ Alistair McMillan, 'The Election Commission', in NG Jayal \& PB Mehta, The Oxford Companion to Politics in India (Oxford University Press 2010) 98.

${ }^{73}$ Singh \& Roy (n 5) 181.

${ }^{74}$ David Gilmartin \& Robert Moog, 'Introduction to “Election law in India”' (2012) 11(2) Election Law Journal 136, 139.

${ }^{75}$ David Gilmartin, ‘One Day's Sultan: TN Seshan and Indian Democracy' (2009) 43(2) Contributions to Indian Sociology 247.

${ }^{76} \mathrm{M}$ Mohsin Alam Bhat \& Anant Sangal, 'Embedding Democratic Ethics: The Case of the Model Code in India's Electoral Governance' (unpublished paper, on file with author).
} 
adjudicate or penalize all the Code violations. In fact, the ECI only adjudicated 66 percent of the total complaints. Out of these, it found violations in at least 40 percent of instances. In 7.6 percent of instances, it imposed penalties in the form of prohibitory orders or bans of election campaigning. It merely forwarded the remaining instances - making up a considerably large proportion of 34 percent - to be handled via ordinary legal mechanisms. These included asking the police to either investigate or file complaints under penal or election legislation.

As I have argued elsewhere, ${ }^{77}$ this shows that the ECI enforces the Code for two separate purposes. In most cases, it channels the potential violations to normal legal routes. By doing this, the ECI ensures that no potential violation slips through ordinary legal enforcement. This also strengthens the efficacy of the legislative framework in case there is an election petition disputing the result. The ECI also implements the Code as a symbolic mechanism. Our data show that the ECI directly enforces penalties only in instances involving high-profile candidates or cases that are particularly egregious. By focusing on such cases, which are often the focus in national media, the ECI expresses electoral ethics. It emphasizes the boundaries of legitimate democratic behaviour.

These channelling and expressive functions of the Code highlight the fact that the ECI implements it as a nudge. The manner of the ECI's implementation of the MCC does not seek a full - or one might say legal - implementation. It still leaves open the choice for political actors to not follow the MCC. This method of implementation does not treat the Code as another tool of enforcing legal norms through prohibitions and penalties. It uses prominent instances to publicize violations that (potentially) facilitate greater public scrutiny. This may, at least theoretically, encourage political actors to stick to electoral ethics that they have themselves agreed to be bound by. The channelling function also fits with the concept of a nudge. Channelling heightens the possibility of legal enforcement of legislation, and creates stronger incentives for political actors to follow ordinary election rules. The subjects of nudge are not so much the persons who the ECI penalizes, but the larger spectrum of political actors who are nudged by a combination of publicization of democratic values, the fear of being identified by the ECI that may cost political reputation among the electorate, and a relatively higher probability of the ordinary legal system taking action against them. Like architectural regulation, the ECI exercises a high degree of discretion while enforcing these nudge-based regulations. The institution can decide which defaulters to directly discipline, and in what instances channelling to ordinary procedures makes more strategic sense. It is therefore not surprising that the ECI's enforcement of the Code has consistently been a subject of political controversy, with critics pointing out its selective invocation. ${ }^{78}$ While there may be cases where such criticism is valid, there is a need to appreciate the fact that this margin of institutional choice is inherent in the very regulatory character of the Code.

\section{Regulating through notice}

The third facet of India's electoral governance is the enforcement of disclosure requirements. This has received the widest scholarly attention, especially for the prominent role of judicial activism in driving this area of regulation. ${ }^{79}$ Since early-1990s, a number of policy recommendations sought to address what was perceived to be a grave crisis of criminalization of Indian politics. India's Law

\footnotetext{
${ }^{77}$ ibid.

${ }^{78}$ See Shashi Tharoor, 'Turn India’s Model Code of Conduct into Law, and Prevent Future EC Bias' The Print (14 May 2021) $<$ https://theprint.in/opinion/turn-indias-model-code-of-conduct-into-law-and-prevent-future-ec-bias/234959> accessed 15 August 2021; M Mohsin Alam Bhat, 'ECI Is Not up to the Task of Sanitising a Chaotic Electoral Process' The Wire (4 June 2019) <https://thewire.in/politics/election-commission-model-code-hate-speech-religion> accessed 15 August 2021.

${ }^{79}$ For some important literature on the topic, see Ronojoy Sen, 'Identifying Criminals and Crorepatis in Indian Politics: An Analysis of Two Supreme Court Rulings' (2012) 11(2) Election Law Journal 216; Manoj Mate, 'The Rise of Judicial Governance in the Supreme Court of India' (2015) 33 Boston University International Law Journal 169; Gurharpal Singh, 'Understanding Political Corruption in Contemporary Indian Politics' (1997) 45(3) Political Studies 626.
} 
Commission, which recommends law reform to the government, suggested far-reaching legal changes including amendments in election legislation to debar candidates with certain severe criminal convictions, to mandate disclosure requirements, and to place limits on election spending. ${ }^{80}$ In the absence of any concrete political initiatives, the Supreme Court in a series of cases mandated that candidates must release the details of their assets and criminal antecedents. ${ }^{81}$ The Court invoked and developed the concept of democracy as a basis for broadening transparency requirements for candidates. ${ }^{82}$ It held that the citizens' right to know was central for a well-functioning democracy, and for the purity and integrity of the electoral process. In these judicial interventions, the ECI became the Court's "ally in electoral reform" ${ }^{83}$ Pursuant to the Court's directions, it introduced a series of disclosure requirements, which mandated that candidates furnish and publicise their income, pending criminal cases and convictions, movable and immovable assets, dues to public financial institutions and government, education and profession. ${ }^{84}$ These requirements were independent of the legislative framework. They also overrode it. When Parliament tried to narrow down these court-mandated requirements, the Supreme Court struck down these attempts. ${ }^{85}$

A useful way to interpret these forms of electoral governance are what scholars of regulation have called notice. Regulators may adopt regulations that, while sharing some similarity with nudges, seek to encourage subjects to deliberate their choices more than they ordinarily would. This would be a case when the regulator demands that a seller place disclosure of ingredients including the calorie count on food packages. For many scholars, notice may be a type of nudge. But for analytical clarity, I classify certain kinds of regulations - what Sunstein notes as "disclosure, warnings, and reminders" notice. This is because notice seeks to inform the subjects of regulation. Nudges on the other hand derive their effectiveness not so much from providing information, as generating emotional reactions leading to desirable behaviour. The significant thing about notice is that it does not seek to impose decisions on the subjects. As Sunstein puts it, the paternalism in notice is soft and means-oriented: "It is soft insofar as it avoids coercion or material incentives, and thus fully maintains freedom of choice. It is means-oriented insofar as it does not attempt to question or alter people's ends."

Interpreting disclosure requirements as notice illuminates their character as a form of regulation. While disclosure requirements apply to candidates, who they really regulate is the electorate. Disclosures aim not to foreclose electoral choice. Like all cases of notice, disclosure requirements are optimistic. They hope that the voters are moved by the information that regulators provide them, and consequently choose wisely. In a significant case involving disclosure reform for instance, the Supreme Court emphasised that it did not seek to direct voters in any direction. The decision of a voter, it noted, "would be based on his own relevant criteria of selecting a candidate." ${ }^{7}$ The voter has the choice "whether holding of educational qualification or holding of property is relevant for electing or re-electing a person," or "whether he should cast vote in favour of a candidate who is involved in criminal case." ${ }^{\text {" }}$ But for this choice to be meaningful - or in the Court's words, "[f]or

\footnotetext{
${ }^{80}$ Law Commission of India, 'One Hundred Seventieth Report on Reform of the Electoral Laws' (Indian Law Com No 170, 1999) <https://lawcommissionofindia.nic.in/lc170.htm> accessed 2 January 2021. See too Vohra Committee Report (Ministry of Home Affairs, Government of India 1993), s $6.2<\mathrm{https} / /$ adrindia.org/sites/default/files/VOHRA\%20COMMITTEE\% 20REPORT_0.pdf $>$ accessed 3 January 2021 (describing the politics-crime nexus).

${ }^{81}$ Union of India v Association for Democratic Reforms [2002] 5 SCC 294; People's Union for Civil Liberties v Union of India [2003] 4 SCC 399.

${ }^{82}$ Bhat (n 56). See also Mate (n 79).

${ }^{83}$ Bhat (n 56).

${ }^{84}$ See Election Commission of India, 'Handbook for Candidates' (2018) 25-26 <https://eci.gov.in/files/file/5392-handbookfor-candidates/> accessed 4 January 2021. For the law of disclosure more generally, see Devi \& Mendiratta (n 16) $542-555$.

${ }^{85}$ See People's Union for Civil Liberties (n 81).

${ }^{86}$ Cass R Sunstein, 'Foreword: The Ethics of Nudging', in Alberto Alemanno \& Anne-Lise Sibony (eds), Nudge and the Law: A European Perspective (Hart Publishing 2015) v, xvii.

${ }^{87}$ Association of Democratic Reforms (n 81) para 22.

${ }^{88}$ ibid para 22.
} 
maintaining purity of elections and healthy democracy" 89 - voters must be "sufficiently informed so that they may influence intelligently the decisions which may affect [them]." ${ }^{\circ 0}$ While the Court was careful not to frame disclosure as determining voter choice, the substance of disclosure was based on what it thought was desirable democratic choice. Thus, the Court's caveat notwithstanding, disclosure requirements as notice-based regulation involves wide discretion, which like architectural and nudge-based regulation, significantly constitutes electoral behaviour. Despite their subtlety - and in many way, precisely because of it - notice regulations shape, or hope to shape election outcomes. This is why decisions about what candidates must disclose matters.

An expression of these high stakes is the consequential and unresolved controversy over campaign finance. In 2017, the BJP-led central government pushed through contentious reforms in Parliament that exempted political parties from disclosing sources of funding received through electoral bonds filed in banks. ${ }^{91}$ Evidence suggests that political parties have received the majority of campaign finance in the last three years through this route. ${ }^{92}$ The ruling BJP has received two-thirds of the total amount donated through electoral bonds. ${ }^{93}$ Corporates are not bound by any contribution limits or disclosure requirements, and have already contributed more than 92 per cent - approximately 919 million US dollars - of the total donations under the scheme. ${ }^{94}$ This complete lack of transparency has alarmed analysts. ${ }^{95}$ Civil society organizations challenged this policy, arguing that the voters had the right to know the identity of donors in order to make an informed democratic choice. Initially expressing concerns regarding the scheme's opacity, the ECI later aligned its position with the government's, arguing in favour of the policy for reducing financing through unaccounted cash. The Supreme Court, apparently influenced by the ECI's position, decided not to intervene until the final hearing, which is yet to happen despite the passage of numerous consequential elections heavily funded through electoral bonds. The electoral bonds controversy indubitably shows that disclosure can influence voter behaviour and hence electoral outcomes. Behind the assertion of the petitioners that the voters had a right to know, was an appreciation that the information about corporate funding may - or should - determine voter choice. ${ }^{96}$ The quality and extent of disclosure is not a mechanical decision, but a discretionary one of great political consequence. In mandating disclosure of criminal antecedents but not the identity of large corporate funders, the Court decides the factors that shape how voters should - and would - make democratic decisions.

\section{The challenge of accountability}

There is a fierce debate on the advantages and limitations of the extra-legal regulations I have discussed until now. This debate has focused on regulations that alter choice architecture based on the principles of behavioural economics. Its substance though applies broadly to any ANN regulation.

\footnotetext{
${ }^{89}$ ibid para 22.

${ }^{90}$ ibid paras 33-34.

${ }^{91}$ See Association for Democratic Reform, 'Electoral Bonds and Opacity in Political Funding' (10 August 2021) < https:// adrindia.org/sites/default/files/ElectoralBondsNote_March_July2021_updated.pdf> accessed 15 August 2021.

${ }^{92}$ ibid.

${ }^{93}$ ibid.

${ }^{94}$ ibid.

${ }^{95}$ See Shahabuddin Y Quraishi, 'Supreme Court Could have Removed Secrecy around Electoral Bonds. Too Bad it Didn't' The Indian Express (8 April 2021) <https://indianexpress.com/article/opinion/columns/supreme-court-transparency-electionfunding-7263402> accessed 15 August 2021 (for CEC arguing that the electoral bonds scheme will introduce opacity and corruption in the Indian democratic process).

${ }^{96}$ During the hearings, Prashant Bhushan, the lawyer representing the petitioners argued that the matter was "...a question of democracy. The electors have the right to know the source and background. If you remove transparency in political funding, it goes to the heart of electoral democracy." See 'Supreme Court Reserves Orders on Plea to Stay Electoral Bonds; Election Commission Opposes Stay’ Live Law (24 March 2021) <https://www.livelaw.in/top-stories/supreme-court-reserves-orderson-plea-to-stay-electoral-bonds-171639> accessed 15 August 2021.
} 
The advocates of ANN regulations have insisted that they are attractive because they involve considerably lesser coercion compared to ordinary legal measures. The absence of legal sanctions leaves open more space for individual choice. Scholars like Thaler and Sunstein have defended ANN as forms of soft paternalism, which display greater appreciations for freedom while steering the subjects of regulation towards a better consideration and deliberation of their choices. Others have argued that ANN regulations, especially architectural regulations, are more effective. They are 'selfexecuting' since they do not depend on the constant intervention of the implementing authorities. ${ }^{97}$ Consequently, they are less susceptible to implementation-related blockages. Such regulations may arguably be more uniform and effective.

The critics of ANN, on the other hand, have pointed out the severe limitations of such regulations. First, just because behaviour is not penalized does not mean that the state is not exercising control over its citizens. The contention is that ANN regulations may reduce coercion in some cases, but it is coercion nevertheless. The effectiveness of these regulations may further heighten this concern. This makes ANN regulations normatively risky, and costly for individual freedom. ${ }^{98}$ While direct legal regulation makes compliance a choice, architecture may make compliance automatic. In some cases, such regulations may pose a more serious challenge for privacy interests. ${ }^{99}$ ANN can quite easily amount to unacceptable forms of manipulation, thereby undermining autonomy. ${ }^{100}$ And since ANN regulations are cost efficient, the regulators may adopt them more pervasively than legal sanctions. ${ }^{101}$ The reduced costs for government control may further heighten the risks of such regulation. ${ }^{102}$

The third concern with ANN regulations is most relevant to my argument. Regulators using ANN often regulate without the knowledge of the subjects of regulation. One of the immediate consequences of this is that since state control is hidden, it may escape public and political oversight. ${ }^{103}$ Glaser, a prominent critic of soft paternalism notes,

Hard paternalism generally involves measurable instruments. The public can observe the size of sin taxes and voters can tell that certain activities have been outlawed. Rules can be set in advance about how far governments can go in pursuing their policies of hard paternalism. Effective soft paternalism must be situation specific and creative in the language of its message. This fact makes soft paternalism intrinsically difficult to control and means that it is, at least on these grounds, more subject to abuse than hard paternalism. It is hard to limit soft paternalism because it is so difficult to determine whether a politician or public statement violated linguistic boundaries. ${ }^{104}$

The concern here is that the ANN regulations are both pervasive and potentially insidious. Regulators can influence far-reaching behavioural changes, without resorting to ordinary legal

\footnotetext{
${ }^{97}$ Cheng (n 31) 664.

${ }^{98}$ Sunstein, 'The Ethics of Nudging' (n 86) v; Alberto Alemanno \& Alessandro Spina, 'Nudging Legally: On the Checks and Balances of Behavioral Regulation' (2014) 12(2) International Journal of Constitutional Law 429, 445-448.

${ }^{99}$ Marcus Felson \& Ronald V Clarke, 'The Ethics of Situational Crime Prevention', in Graeme Newman \& Ronald V Clarke (eds), Rational Choice and Situational Crime Prevention (Routledge 1997) 197, 198.

${ }^{100}$ Karen Yeung, 'Nudge as Fudge' (2012) 75 Modern Law Review 122, 147.

${ }^{101}$ Cheng (n 31) 670 ("Structural laws, however, are efficient and relatively inexpensive because they do not require enforcement on a case-by-case basis. Were legislatures to adopt a more structural approach, they would be able to engage in more regulation, further limiting the freedom of the average citizen.").

${ }^{102}$ Lessig (n 10) 148.

${ }^{103}$ Cheng (n 31) 670; Muireann Quigley \& Elen Stokes, 'Nudging and Evidence-Based Policy in Europe: Problems of Normative Legitimacy and Effectiveness', in Alberto Alemanno \& Anna-Lise Sibony (eds), Nudge and the Law - A European Perspective (Hart Publishing 2015) 78, 79.

${ }^{104}$ Edward L Glaeser, 'Paternalism and Psychology' (2006) 73 University of Chicago Law Review 133, 151.
} 
procedures or parliamentary debate. ${ }^{105}$ Thus, there is a lack of deliberative input in framing and implementing ANN regulations. Regulators at various levels of government can adopt, alter and proliferate such regulations with little costs, ${ }^{106}$ considerably strengthening them. Since ANN regulations are flexible, ${ }^{107}$ regulators can easily introduce subtle or dramatic changes that may considerably shape behaviour. And there is always a possibility of regulators making errors. ${ }^{108}$ All these factors indicate a serious deficit of transparency and accountability.

These concerns are further aggravated by the fact that ANN regulations can be and have often been used to undermine the substantive goals of law. For instance, as Lessig points out, local government in the United States managed to upstage the ruling against discriminatory covenants in Shelly $v$ Kramer through architectural means. So-called informal mechanisms of building highways and railroads, and demarcating zoning indirectly maintained segregation. ${ }^{109}$ The challenge, as Lessig notes, is that here,

... the government is regulating indirectly by using the structures of real-space code to effect its ends, but this regulation, again, is not seen as regulation. Here the government gets an effect at no political cost. It gets the benefit of what would clearly be an illegal and controversial regulation without even having to admit any regulation exists. ${ }^{110}$

The proponents of ANN regulations have often conceded this challenge. Sunstein for instance accepts that nudges do "raise special concerns" even when they are not "secret or covert." advocates that since choice architecture is inevitable, democratic governments - through transparent means - are best authorized to regulate in this manner. ${ }^{112}$ The regulators according to him must face "a burden of justification." ${ }^{113}$ ANN regulations must be subject to public scrutiny. ${ }^{114}$

But their scale, complexity and subtlety - in terms of framing and consequences - are inherent practical constraints on transparency and deliberation. The fact that such regulations are hidden may make it difficult for individuals to identify manipulation and challenge it legally and politically. ${ }^{115}$ It is difficult for law to circumscribe legal boundaries for ANN, as they are informal, adaptive, flexible and personalized. ${ }^{116}$ Operational accountability - through judicial review, for instance - is also difficult. Courts cannot treat ANN as ordinary coercive laws. Hence, as Alemanno and Spina point out, "unless there is a full understanding of the social context and of their de facto consequences, they tend to escape the formal judicial scrutiny applicable to the

\footnotetext{
${ }^{105}$ Robert Lepenies \& Magdalena Małecka, 'Behaviour Change: Extralegal, Apolitical, Scientistic?', in Holger Strassheim \& Silke Beck (eds), Handbook of Behavioural Change and Public Policy (Edward Elgar Publishing 2019) 344, 350 ("Behaviour change instruments do not require much political support, parliamentary procedure and debate. In this way, they enable policy-makers to influence people's behaviour more quickly, more effectively, and without putting effort into legislative and deliberative processes."); Calo (n 10) 777.

${ }^{106}$ Lepenies \& Małecka (n 105) 351.

${ }^{107}$ ibid; Christopher McCrudden \& Jeff King, 'The Dark Side of Nudging: The Ethics, Political Economy, and Law of Libertarian Paternalism', in Alexandra Kemmerer, Christoph Möllers, Maximilian Steinbeis \& Gerhard Wagner (eds), Choice Architecture in Democracies: Exploring the Legitimacy of Nudging (Hart Publishing 2016) 75.

${ }^{108}$ Glaeser (n 104) 151.

${ }^{109}$ Lessig (n 10) 135.

110 ibid.

${ }^{111}$ Cass R Sunstein, Why Nudge?: The Politics of Libertarian Paternalism (Yale University Press 2014) 150.

${ }^{112}$ Sunstein (n 86) v; Peter John et al, Nudge, Nudge, Think, Think: Experimenting with Ways to Change Civic Behaviour (Bloomsbury Academic 2011) 23. See too Katyal (n 21) 1132 (arguing that government's architectural regulation is bound to be more accountable and transparent, because it is subject to "special constraints" and "disclosure laws".).

${ }^{113}$ Sunstein, 'The Ethics of Nudging' (n 86) v.

${ }^{114}$ ibid ix; Lessig (n 10) 135-136.

${ }^{115}$ van Aaken (n 65) 94.

${ }^{116}$ Alemanno \& Spina (n 98) 449-450; Alberto Alemanno, 'The Emergence of the Evidence-Based Judicial Reflex: A Response to Bar-Siman-Tov's Semiprocedural Review' (2013) 1(2) The Theory and Practice of Legislation 327.
} 
binding acts of the executive power."117 For this reason, they advocate that courts develop "an evidence-based judicial reflex, by promoting a culture proof, evidence and rationality in adjudicating..."118 This is not an easy task because the legal effects of ANN are disguised. The opacity of ANN regulations appears to be endemic to their very nature.

Perhaps because of this, ANN advocates have defended the legitimacy of such regulations not on operational accountability but to the merit of their outcomes. Thaler and Sunstein's main response to the objections is that "the evaluation of nudges depends on their effects-on whether they hurt people or help them." 119 It follows that the legitimacy of ANN depends on the regulator's level of expertise. ${ }^{120}$ By extension, it would depend on the regulator's ability - competence and independence - to shape behaviour through extra-legal modalities.

This discussion has important consequences for our evaluation of powerful EMBs like the ECI. It reframes and brings precision to the concerns raised by numerous scholars of Indian elections that the ECI expanding functions threaten its credibility. As I have attempted to argue, the issue is not as much about the repertoire of functions, but the character of the exercise of power. The ECI has expanded its functions not merely in the domain of ordinary administrative action. ${ }^{121}$ It has increasingly come to play a profound role in determining the behaviour of voters and political actors through extra-legal regulations. By their very nature, such regulations are susceptible to accountability deficit. The extent, depth and quality of the ECI's architectural regulation places practical limits to political or legal operational accountability. This may also partly explain why worries about the ECI's fair-handedness - especially among India's political opposition - have been perennial. The political and often high-pitched debate about the ECI's fairness is very much part of the institution's history. More recently, political actors have criticized the ECI's implementation of the Code and scheduling of elections. ${ }^{122}$ Political critics have suggested that the ECI is under government's pressure. ${ }^{123}$ My account suggests that these concerns are bound to arise because the ECI exercises functions that are granular, discretionary, subtle, and constitutive as forms of regulations.

\section{Volatile structural accountability}

Until now, I have argued that the extra-legal ANN regulations of the ECI pose a special challenge for accountability. The character of the ECI's regulation through architecture, nudge and notice do not lend themselves to oversight and transparency easily. In other words, there are endemic limitations to operational accountability. This indicates that that heavier burden must fall on the other mode of accountability: structural accountability. As I have argued elsewhere, powerful fourth-branch EMBs are best interpreted as trustee institutions. ${ }^{124}$ They are expected to function as politically insulated

\footnotetext{
${ }^{117}$ Alemanno \& Spina (n 98) 452.

${ }^{118}$ ibid 454-455. See van Aaken (n 65) for an attempt to apply judicial review to ANN modalities.

${ }^{119}$ Thaler \& Sunstein (n 64) 247.

120 ibid.

${ }^{121} \mathrm{My}$ aim is not to make a strong claim about the essential meaning of administration, but only to point a contrast between the EMBs' managerial role, as against their regulative and constitutive roles. For the sake of this contrast, I am relying on an admittedly narrow conception of administration, as politically disinterested and mechanistical implementation of public law. For this conception of administration see Graham Allison, 'Emergence of Schools of Public Policy: Reflections by a Founding Dean' in Michael Moran, Martin Rein \& Robert E Goodin (eds), The Oxford Handbook of Public Policy (Oxford University Press 2008) 61.

${ }^{122}$ For a recent instance, see Snigdhendu Bhattacharya, 'Spread Over a Month, Bengal's Eight-Phase Election Triggers New Political Debate' The Wire (27 February 2021) <https://thewire.in/politics/spread-over-a-month-bengals-eight-phase-election-triggers-new-political-debate> accessed 1 March 2021.

${ }^{123}$ See eg, Sidharth Bhatia, 'The Reputation of the Election Commission Has Been Severely Tarnished' The Wire (20 May 2019) <https://thewire.in/government/elections-2019-election-commission> accessed 2 March 2021; Sanya Dhingra, 'This is not an easy time to be the Election Commission of India. Here's why' The Print (13 April 2019) <https://theprint.in/opinion/newsmaker-of-the-week/this-is-not-an-easy-time-to-be-the-election-commission-of-india-heres-why/220995> accessed 3 March 2021.

${ }^{124}$ Bhat (n 56).
} 
institutions for the purpose of securing the democratic process. The political system by extension must create mechanisms to secure the conditions of their trustworthiness, specifically their ability to maintain credible commitments over time. This would imply creating processes that protect their independence, competence and neutrality. The tenuousness of operational accountability highlights the crucial role that the other modes of accountability play in accomplishing this. It specifically raises the stakes for structural accountability. Structural accountability mechanisms include securing the conditions of appointment, tenure and service of the ECI's leadership; guaranteed budgetary allocations; and the independence of a competent body of functionaries.

The ECI's structural accountability though has historically remained a ticklish subject. While India's constitutional framers were keen on securing the electoral process through a non-executive institution, they surprisingly did not provide substantial protection from interference. The Constitution has provided neither a politically insulated nor a bipartisan appointment process for the institution's leadership. It has left the appointment of the permanent CEC to the Executive, subject to parliamentary legislation. ${ }^{125}$ It envisages a multi-member institution, but has left the appointment of additional election commissioners to the Executive. ${ }^{126}$ The Constitution has secured the CEC's tenure and conditions of service, who could be removed only though an impeachment process analogous to that for a Supreme Court judge. ${ }^{127}$ But it has not done so for the additional election commissioners, who can be removed by the Executive, provided this is also recommended by the CEC. ${ }^{128}$

Unsurprisingly then, a considerable body of literature has suggested legal reform to secure the institution's independence. ${ }^{129}$ The suggestions in particular have focused on making the appointment, tenure, and conditions of service of the additional election commissioners in para materia with the CEC. ${ }^{130}$ The ECI has also demanded a permanent secretariat with officials at all levels insulated from political pressure. ${ }^{131}$ The concern has been that since the ECI borrows officials from normal governance services during elections, its functioning depends on executive fiat.

The precariousness of the ECI's structural accountability is best revealed by the thorny history of the politicization of appointments. The Supreme Court's involvement, rather than ameliorating this problem, has further exacerbated it. One of the main areas of concern is the possibility of packing through executive appointments of additional election commissioners. Until 1989, the ECI was a single member institution with a permanent CEC. In October 1989, the Congress Party-led government created and filled two new positions through an executive order. The party lost the national election soon after. Reportedly for political reasons, ${ }^{132}$ the new government rescinded the positions and appointments in January 1990. The CEC, who had opposed the original appointments, stated on record that he agreed with the rescission as a matter of policy. But he also maintained that he had not made any recommendation for removal. One of the former election commissioners challenged his removal by way of judicial review. The question before the Supreme Court in Dhanoa was whether the additional election commissioners could be removed - by rescinding the positions

\footnotetext{
${ }^{125}$ Constitution of India, art 324(2).

${ }^{126}$ ibid.

${ }^{127}$ Constitution of India, art. 324(5).

${ }^{128}$ ibid.

${ }^{129}$ For some key government reports, see Core-Committee on Electoral Reforms, 'Background Paper on Electoral Reforms' (December 2010) <https:/lawmin.gov.in/background-paper-electoral-reforms> accessed 30 May 2021; Election Commission of India, Proposed Electoral Reforms (August 2004), <https://eci.gov.in/files/file/3106-electoral-reforms/> accessed $30 \mathrm{May}$ 2021; Ministry of Law and Justice of India, 'Report of the Committee on Electoral Reforms' (May 1990) <https://adrindia. org/sites/default/files/Dinesh\%20Goswami\%20Report\%20on\%20Electoral\%20Reforms.pdf> accessed $30 \quad$ May 2021; 'Proposed Electoral Reforms' (n 52); 'Report No. 255' (n 55).

${ }^{130}$ ibid, 'Report No. 255' (n 55) 99-108.

${ }^{131}$ 'Proposed Electoral Reforms' (n 52) 5.

${ }^{132}$ James Michael Lyngdoh, Chronicle of an Impossible Election: The Election Commission and the 2002 Jammu and Kashmir Assembly Elections (Penguin India 2004) 67.
} 
altogether - without fulfilling the constitutional requirement of the CEC's recommendation. ${ }^{133}$ The petitioner among other things argued that for the ECI to remain independent from executive influence, the recommendation of the CEC was mandatory. ${ }^{134}$ In its defence, the government asserted that it had initially anticipated the need for additional commissioners due to the lowering of the voting age. But with the benefit of more information, it had come to the conclusion that no such change was required after all. It argued that it had complete discretion, "without any limitation", to determine the number of election commissioners. ${ }^{135}$

The Supreme Court held that the government's decision did not amount to termination of service, but "abolition of posts". ${ }^{136}$ The constitutional requirement of the CEC's recommendation would thus not apply. The Court took the position that the ECI was fundamentally a single-member body under the constitutional scheme. This meant that, first, the CEC was not one among equals but superior to the other commissioners. ${ }^{137}$ Second, the fact that the Executive or Parliament had not provided a clear and detailed definition of the role of the additional commissioners meant that the "appointments were an oddity". ${ }^{138}$ Consequently, "the abolition of the posts", the Court held, "far from striking at the independence of the Commission paved the way for its smooth and effective functioning." "139 This formulation, though, reflected an awkward assessment of institutional independence. The distinction between termination of service and abolition of posts was tenuous at best, because both amounted to the same thing in terms of its impact of the ECI's independence. The Court's decision meant that the Executive could appoint additional commissioners in a transitory manner and remove them later at its whim.

Dhanoa was short-lived. In 1993, the Congress Party came back to power and passed legislation to add two additional commissioners again, along with norms and procedures detailing their role on the ECI. The precipitating factor this time was to dilute the power of the activist CEC T.N. Seshan, who had publicly come into conflict with the government over his assertive implementation of electoral norms. ${ }^{140}$ Seshan challenged the legislation, including on the ground that it was mala fides. ${ }^{141} \mathrm{He}$ argued that by appointing two more commissioners and giving them an equal voting power on the ECI, the government wanted to "sideline the CEC and to erode his authority so that the ruling party at the centre could extract favourable orders by using the services of the newly appointed ECs." 142

The Supreme Court in Seshan overruled Dhanoa, but in the process tied itself in knots. It noted that contrary to Dhanoa, the Constitution envisaged a multi-member ECI. ${ }^{143}$ It also held that the Constitution did not place the CEC at a superior status to the other commissioners. ${ }^{144}$ Consequently, the Court held that Parliament was well within its powers to pass the legislation. ${ }^{145}$ This formulation posed a serious problem for the ECI's independence. The equal decision-making powers of the additional commissioners would allow them to out-vote the CEC. But it was only the

\footnotetext{
${ }^{133}$ SS Dhanoa $v$ Union of India [1991) 3 SCC 567.

${ }^{134}$ ibid para 3.

${ }^{135}$ ibid para 4.

${ }^{136}$ ibid para 29.

${ }^{137}$ ibid para 11.

138 ibid para 28.

${ }^{139}$ ibid para 28.

${ }^{140}$ See Christophe Jaffrelot, 'T.N. Seshan and the Election Commission', in Shahabuddin Y Quraishi (eds), The Great March of Democracy: Seven Decades of India's Elections (Penguin Books 2019)104, 106-107. On Seshan's leadership of the ECI more generally, see David Gilmartin, 'One Day's Sultan: TN Seshan and Indian Democracy' [2009] 43 (2) Contributions to Indian Sociology 247.

${ }^{141}$ TN Seshan, Chief Election Commissioner of India v Union of India [1995] 4 SCC 611.

${ }^{142}$ ibid para 7.

${ }^{143}$ ibid para 12.

${ }^{144}$ ibid paras $18-20$.

${ }^{145}$ ibid para 36.
} 
CEC who legally had a higher degree of protection from removal - and hence greater insulation from political influence. The additional commissioners on the other hand could be removed either with the recommendation of the CEC, or, as in the case of Dhanoa, by rescinding the positions altogether.

This precarious situation was evidently presented to the Court. The Court noted, appreciating the centrality of independence, that the Constitution had created the ECI so that it may be "entrusted the task of holding elections to the legislatures should be fully insulated so that it can function as an independent agency free from external pressures from the party in power or executive of the day." 146 But it did not fully develop what the requirement of institutional independence would entail in this particular case. It merely noted that this independence would be the responsibility of the CEC who had been insulated from political pressure, to ensure that the ECI was "not at the mercy of political or executive bosses of the day." 147 The commissioners "have been assured independence of functioning", the Court reasoned, "by providing that they cannot be removed except on the recommendation of the CEC." "148 The Court did not consider whether the lack of security of tenure and conditions of the additional commissioners would weaken the ECI's independence if, at the same time, the ECs had the same decision-making powers as the more secure CEC. It over-ruled Dhanoa when it came to the parity of election commissioners. But it did not touch Dhanoa when it came to the vulnerability of the additional commissioners.

What was missing in Seshan was the appreciation - and crucially, a theory - of institutional independence. ${ }^{149}$ Numerous constitutionally viable routes were available to the Supreme Court. While it may not have been able to justify prohibiting the government from appointing additional commissioners, it could have demanded their parity with the CEC in terms of tenure and removal. Or the Court could have, in the absence of parity, insisted on the primacy of the CEC's decisions, because that would ensure the ECI's independence. These might have been some options for the Court in place of a clearly legislated policy of institutional independence. Doubtlessly, in the long run, the most appropriate route for the ECI's structural accountability is a constitutional amendment or legislation that provides all the election commissioners a robust - and equal - protection from political pressure. This would entail a politically inclusive and deliberative appointment process, and security of the term and conditions of tenure. These reforms for structural accountability are imperative, especially considering the inherent limitations of operational accountability I have pointed out.

\section{Conclusion}

The chief purpose of this Article was to highlight the dilemma of accountability in the case of powerful EMBs. Through the account of the ECI's functions, the Article sought to illuminate how powerful EMBs do much more than merely manage elections. They constitute the democratic process. Electoral regulation structures the electoral architecture that determines the conditions of entry and participation of political actors, and frames and steers the electoral choice of voters. This is a particularly germane description of the ECI, which exercises a wide discretion determining electoral behaviour. The Indian Supreme Court has interpreted the ECI's powers to run parallel to - and sometimes even override - parliamentary powers The ECI's regulations are subtle, both in form and consequences. The institution has adopted extra-legal modalities of regulation, specifically architecture regulation, nudge and notice. The dilemma of accountability results from this

\footnotetext{
${ }^{146}$ ibid para 10.

${ }^{147}$ ibid para 11.

${ }^{148}$ ibid para 11.

${ }^{149}$ As Michael Pal rightly observes, "The Supreme Court of India has been equally culpable of failing to develop doctrine to address partisan self-dealing." See Pal (n 5) 40. For a critique on similar lines, see Ramaswamy R Iyer, 'The Election Commission and the Judgment' (1996) 31 Economic and Political Weekly 37.
} 
nature of the ECI's powers. While these modalities of regulation are powerful mechanisms for creating a democratic landscape suited for electoral activity, they are also potentially insidious, and consequently pose a special problem for operational accountability. These intractable features of electoral regulation raise the stakes for structural accountability. But, as I have tried to argue, this mode of accountability in the case of India has remained vulnerable and precarious. In light of this, there is thus an even more urgent need to secure the ECI's independence through legal reform.

Acknowledgements. The author would like to thank Rosalyn Dixon, Mark Tushnet, Mike Pal, James Fowkes, Tarunabh Khaitan, Aradhya Sethia, Iain Payne and Dinesha Samararatne for their comments and suggestions. Previous versions of this Article were presented at the Democratic Constitutions and Electoral Commission Workshop, organized by the Gilbert + Tobin Centre of Public Law, UNSW Sydney, and the Fourth Branch South Asia Workshop, organized by Niti Foundation, Nepal. Thanks to Aparajito Sen for research assistance. 